\title{
Insecticide Distribution Model in Human Tissues Viewing Worker's Health Monitoring Programs
}

\author{
Lourival Costa Paraíba, Vera Lúcia Scherholz Salgado de Castro* and Aline de Holanda \\ Nunes Maia \\ Embrapa Meio Ambiente; Rodovia SP 340, km 127.5, C. P. 69; 13820-000; Jaguariúna - SP - Brasil
}

\begin{abstract}
This work aimed at evaluating the characteristics of thirty nine insecticides on tissue distribution and accumulation, using their physico-chemical characteristics and the tissues lipid contents to calculate the compounds distribution among the tissues. The insecticides evaluated were selected among those registered in Brazil for agriculture use. The level I fugacity model was used for the calculations of insecticide distribution among the tissues of muscles, viscera, skin, fat, blood, liver, kidneys and gut. The octanol-water partition coefficient, water solubility and tissue lipid contents showed an insecticide distribution in human tissues. Cluster analysis was performed aiming the identification and separation of insecticides groups based on their physico-chemical characteristics as compounds with similar distribution within tissues and at the same time tissues with similar distribution of various insecticides. Cluster analysis pointed out three insecticide groups: in the first, 70 - 86\% of insecticide accumulation was found in lipid tissues; in the second, $44-58 \%$; and in the third, $9-19 \%$. These results could contribute to health monitoring programs of farmworkers.
\end{abstract}

Key words: Fugacity model, Insecticide tissue distribution, Farmworkers, Health monitoring programs

\section{INTRODUCTION}

Pesticides are used worldwide to increase the productivity in agriculture and Brazil is the one of the major markets for pesticides. In the field, pesticide use may result in farmworkers' intoxication in many degrees and represents a serious public health concern, mainly in developing countries (Caldas and Souza, 2000). Pesticide exposures occur during mixing, inhaling fumes while spraying and from saturated work clothes. General agricultural workers and rural communities are also affected by the spray drift by washing work clothes, use of pesticide containers for food or water storage, polluted drinking water, or proximity to obsolete pesticide dumps.
Pesticide poisoning is a daily hazard for the majority of the world's rural population. It affects both the health and environment. Human exposure to pesticides can result in severe health injuries in consequence of frequent contacts even in small doses (Castro et al., 1999).

Insecticides, especially organophosphorus and carbamates are the main cause of human intoxication during field labor. Chronic low-level exposure to them has also been implicated as a causal factor in a variety of different forms of human ill-health (Murray et al., 2005). Organophosphorus and carbamate insecticides are absorbed by oral or respiratory intake or skin contact and their toxicities are affected by the vehicle, route of exposure and environmental conditions. They are rapidly absorbed and

\footnotetext{
*Author for correspondence: castro@cnpma.embrapa.br
} 
distributed to the tissues. Also, their metabolism and elimination are relatively fast (Jaga and Dharmani, 2003). In addition, there is evidence that the acutely toxic organophosphate class of pesticide can also exacerbate the breakdown of the body's immune system (Dinham and Malik, 2003).

Organophosphate poisoned populations have shown a consistent pattern of deficits when compared to a non-exposed or non-poisoned population on measures of motor speed and coordination, sustained attention, and information processing speed (Rohlman et al., 2007). Therefore, some studies have indicated depressive symptoms associated to organophosphorus insecticide exposure, while other reports have related acute intoxications to pesticide exposure and to prevalent signs related to the nervous system functions and minor psychiatric perturbations. The most frequent diagnosis was depression and anxiety (Levigard and Rozemberg, 2004).

One challenge in quantitative health risk assessment arises from the need to have models for dosimetry, i.e., the delivery of active forms of test molecules/metabolites to target tissues (Andersen et al., 2005). Actions need to be established to obtain hazard assessment knowledge and toxicant exposure prevention measures, which require a wide and integrated view relating health and environment. Such information can be used, for example, in monitoring programs for worker's health or for consumers that are exposed to insecticides, or else, in experimental evaluations.

A toxicant-exposed population monitoring carried out with the objective of detecting possible hazards to human health, can be performed through direct or indirect procedures, consisting of serial evaluations and interpretations of biological and environmental parameters. Thus, additional investigations are necessary to obtain more information about which human tissues insecticides might accumulate. Mathematical modeling may be used with data originated from biomarkers measures, aiming to describe the toxicant distribution in several organisms' compartments as a function of the compartment and the toxicant physical-chemical properties.

Mathematical models might contribute to predict pesticide concentrations in human tissues. The fugacity models have been used in the estimation of organic compound in human or human tissues (Maruyama et al., 2002; Moser and Mc Lachlan,
2002; McKone and MacLeod, 2003; Czub and McLachlan, 2004). Fugacity is expressed in pressure units and describes the organic compound escaping tendency from a compartment, tissue, medium or phase. Hence, the fugacity models allow calculation of the pesticide total mass distribution among the environmental systems or organisms' compartments. The fugacity model is classified in levels I, II, III and IV as a consequence of the assumed hypothesis and calculations involved in the formulation of each level (Mackay, 2001; Paraíba et al., 2002).

Screening test systems are essential for cost savings, which are extremely relevant for testing the numerous pesticides that a farmworker can be exposed. Above all that, knowledge of the pharmacokinetics/dynamics of a chemical may suggest a suitable risk model. Aiming to study a screening method of insecticide distribution on human tissues, the present work estimated the distribution of thirty nine insecticides using level I fugacity model among theoretically and continuously exposed human tissues, and to indicate the main insecticides and tissues for samplings to be collected in health monitoring programs.

\section{MATERIAL AND METHODS}

The insecticides evaluated in the present work were selected among those registered for agriculture use in Brazil and those having the required information for the fugacity model in the literature.

The level I fugacity model was applied to estimate the percent distribution of thirty nine insecticides among human tissues: muscles, viscera, skin, fat, blood, liver, kidney and gut, assuming a person body mass of $70 \mathrm{~kg}$. The fugacity of a pesticide is related to its concentration, $\mathrm{C}\left(\mathrm{mol} \mathrm{m} \mathrm{m}^{-3}\right)$, by the fugacity capacity, $\mathrm{Z}\left(\mathrm{mol} \mathrm{m} \mathrm{m}^{-3} \mathrm{~Pa}^{-1}\right)$, in the compartment for a specific insecticide. Intuitively, the fugacity capacity expresses the pesticide solubility in a compartment. The concentration is estimated by $\mathrm{C}=\mathrm{Zf}$ where $\mathrm{f}(\mathrm{Pa})$ is the pesticide fugacity in the compartment. In a steady-state equilibrium system, pesticide fugacity from the tissues might be set equal. Thus, due to the proportionality between $\mathrm{C}$ and $\mathrm{Z}$, tissues with high fugacity capacities for an insecticide will also show high insecticide concentrations. 
The fugacity capacity in every tissue and for each insecticide was estimated by the sum of fugacity capacity of water volumetric fraction in that tissue and the fugacity capacity of lipid volumetric fraction in the same tissue, that is, $\mathrm{Z}_{\mathrm{i}}=\frac{\left(1-\lambda_{\mathrm{i}}\right)}{\mathrm{H}}+\frac{\lambda_{\mathrm{i}} \mathrm{K}_{\mathrm{ow}}}{\mathrm{H}} \times \frac{\rho_{\mathrm{i}}}{\rho_{\mathrm{w}}}$, where $\mathrm{H}\left(\mathrm{Pa} \mathrm{m}^{3} \mathrm{~mol}^{-1}\right)$

is the Henry's law constant for the insecticide, $\lambda_{\mathrm{i}}$ is the lipid volumetric content of tissue $\mathrm{i}, \mathrm{K}_{\mathrm{ow}}$ is the octanol-water partition coefficient, $\rho_{w}$ is the water density $\left(1000 \mathrm{~kg} \mathrm{~m}^{-3}\right)$ and $\rho_{\mathrm{i}}\left(\mathrm{kg} \mathrm{m}^{-3}\right)$ is the tissue density (Cahill and Mackay, 2001; Maruyama et al., 2002).

In the level I fugacity model, all insecticide fugacity values are assumed to be equal and constant, that is, $\left(f_{i}=f_{j}=f\right)$ for every $\mathrm{i}, \mathrm{j} \in \mathrm{J}, \mathrm{J}=\{\mathrm{M}, \mathrm{V}, \mathrm{S}, \mathrm{F}, \mathrm{B}, \mathrm{L}, \mathrm{K}, \mathrm{G}\}$, where $\mathrm{M}=$ muscles, $\mathrm{V}=$ viscera, $\mathrm{S}=$ skin, $\mathrm{F}=$ fat, $\mathrm{B}=$ blood, $\mathrm{L}=$ liver, $\mathrm{K}=$ kidney and $\mathrm{G}=$ gut. From this supposition, if each compartment $j \in J$ was a well-defined volume $\mathrm{V}_{\mathrm{i}}$. Thus, the percent distribution of insecticide $m$ in tissue $i$ is estimated by $\mathrm{P}_{\mathrm{i}}^{\mathrm{m}}=\frac{\mathrm{Z}_{\mathrm{i}}^{\mathrm{m}} \mathrm{V}_{\mathrm{i}}}{\sum_{\mathrm{i} \in \mathrm{J}} \mathrm{Z}_{\mathrm{i}}^{\mathrm{m}} \mathrm{V}_{\mathrm{i}}} \times 100$, where $1 \leq \mathrm{m} \leq 39$ are indexes representing insecticides and $\mathrm{Z}_{\mathrm{i}}^{\mathrm{m}}$ is the fugacity capacity of tissue $i$ for the insecticide $m$. Some data of this study were obtained from the literature as tissue volumes (Kissel and Robarge, 1988), lipid volumetric contents and tissue densities (Maruyama et al., 2002). The molar mass, water solubility, vapor pressure, Henry's law constants and octanol-water partition coefficients for the thirty nine insecticides were obtained in SCR (2005), except for the data for abamectin, acetamiprid and lufenuron, which were from Tomlin (2000).

Cluster analysis for insecticides as the tissue distribution pattern similarity was performed using the cluster mean and Euclidian distance as criteria for cluster formation. Cluster analysis for tissues as the insecticide distribution pattern similarity was performed using the method of Ward (Ward,
1963) and the Euclidian distance as criteria for cluster formation.

The calculations were made using a sheet containing the physico-chemical characteristics of every insecticide, the equations to calculate the fugacity capacities, the insecticide percent distributions and the air-water and air-octanol partition coefficients. The cluster analyses were performed using the SAS System procedures PROC CLUSTER and PROC TREE (SAS, 1998).

\section{RESULTS}

Tissue distributions of thirty nine insecticides and their classification in groups and subgroups according to their distribution pattern similarity are presented in Table 1. Fat and muscles were the main compartments tending to accumulate insecticides, since they presented percent fractions higher than $69 \%$ for all the evaluated insecticides. For $90 \%$ of the insecticides (groups 1 and 2), the fraction in fat tissues was estimated to be higher than 50\% (Table 1).

The dendogram resulting from cluster analysis of tissues according to the similarity of insecticide pattern distribution is presented in Fig. 1. The dendogram resulting from the cluster analysis of insecticides in relation to the similarity of human tissue distribution pattern showed that insecticides could be classified in three groups and subdivided in subgroups: the first group consisted of low water solubility insecticides with $\operatorname{LogK}_{\text {ow }} \geq 1.7$ (group 1 and subgroups 1.1, 1.2 and 1.3); the second consisted of intermediate water solubility insecticides with $0.51 \leq \operatorname{LogK}_{\text {ow }} \leq 1.3$ (group 2 and subgroups 2.1 and 2.2); and the third, of high water solubility insecticides with $\log \mathrm{K}_{\text {ow }} \leq-0.2$ (group 3 and subgroups 3.1 and 3.2). A straight line at the 2.8 distance allowed separating three great groups of tissues: the first consisting of liver and kidneys; the second, of gut, muscle, blood, skin and viscera; and the third, of fat. These results pointed out the importance of volumetric lipid contents of tissues in the insecticide percent distribution. 
Table 1 - Insecticide groups and sub groups of similar percentage of distribution in human tissues.

\begin{tabular}{|c|c|c|c|c|c|c|c|c|c|c|}
\hline \multirow{2}{*}{ Insecticides } & \multirow{2}{*}{ groups } & \multirow{2}{*}{ subgroups } & \multicolumn{8}{|c|}{$\%$ distribution } \\
\hline & & & muscle & viscera & skin & fat & blood & liver & kidney & gut \\
\hline abamectin & & & 10.25 & 1.27 & 0.41 & 86.34 & 0.21 & 0.89 & 0.04 & 0.59 \\
\hline acrinathrin & & & 10.24 & 1.27 & 0.41 & 86.35 & 0.21 & 0.89 & 0.04 & 0.59 \\
\hline alfa-cypermethrin & & & 10.24 & 1.27 & 0.41 & 86.35 & 0.21 & 0.89 & 0.04 & 0.59 \\
\hline azocyclotin & & & 10.24 & 1.27 & 0.41 & 86.35 & 0.21 & 0.89 & 0.04 & 0.59 \\
\hline bifenthrin & & & 10.24 & 1.27 & 0.41 & 86.35 & 0.21 & 0.89 & 0.04 & 0.59 \\
\hline carbofuran & & & 11.08 & 1.35 & 0.50 & 85.05 & 0.42 & 0.93 & 0.05 & 0.63 \\
\hline carbosulfan & & & 10.24 & 1.27 & 0.41 & 86.35 & 0.21 & 0.89 & 0.04 & 0.59 \\
\hline chlorfluazuron & & & 10.24 & 1.27 & 0.41 & 86.35 & 0.21 & 0.89 & 0.04 & 0.59 \\
\hline chlorpyrifos & & & 10.24 & 1.27 & 0.41 & 86.35 & 0.21 & 0.89 & 0.04 & 0.59 \\
\hline cyflutrin & & & 10.24 & 1.27 & 0.41 & 86.35 & 0.21 & 0.89 & 0.04 & 0.59 \\
\hline cypermethrin & & & 10.24 & 1.27 & 0.41 & 86.35 & 0.21 & 0.89 & 0.04 & 0.59 \\
\hline deltamethrin & & & 10.24 & 1.27 & 0.41 & 86.35 & 0.21 & 0.89 & 0.04 & 0.59 \\
\hline diflubenzuron & & & 10.26 & 1.27 & 0.41 & 86.31 & 0.22 & 0.89 & 0.04 & 0.59 \\
\hline disulfoton & & 11 & 10.26 & 1.27 & 0.41 & 86.32 & 0.22 & 0.89 & 0.04 & 0.59 \\
\hline endosulfan & & 1.1 & 10.27 & 1.27 & 0.42 & 86.31 & 0.22 & 0.89 & 0.04 & 0.59 \\
\hline ethion & 1 & & 10.24 & 1.27 & 0.41 & 86.35 & 0.21 & 0.89 & 0.04 & 0.59 \\
\hline fenpropathrin & & & 10.24 & 1.27 & 0.41 & 86.35 & 0.21 & 0.89 & 0.04 & 0.59 \\
\hline fenthion & & & 10.26 & 1.27 & 0.41 & 86.33 & 0.21 & 0.89 & 0.04 & 0.59 \\
\hline fipronil & & & 10.26 & 1.27 & 0.41 & 86.32 & 0.22 & 0.89 & 0.04 & 0.59 \\
\hline lambda-cyhalothrin & & & 10.24 & 1.27 & 0.41 & 86.35 & 0.21 & 0.89 & 0.04 & 0.59 \\
\hline lufenuron & & & 10.24 & 1.27 & 0.41 & 86.35 & 0.21 & 0.89 & 0.04 & 0.59 \\
\hline parathion-methyl & & & 10.49 & 1.29 & 0.44 & 85.97 & 0.27 & 0.90 & 0.04 & 0.60 \\
\hline permethrin & & & 10.24 & 1.27 & 0.41 & 86.35 & 0.21 & 0.89 & 0.04 & 0.59 \\
\hline profenofos & & & 10.24 & 1.27 & 0.41 & 86.34 & 0.21 & 0.89 & 0.04 & 0.59 \\
\hline teflubenzuron & & & 10.25 & 1.27 & 0.41 & 86.34 & 0.21 & 0.89 & 0.04 & 0.59 \\
\hline triazophos & & & 10.32 & 1.28 & 0.42 & 86.22 & 0.23 & 0.89 & 0.04 & 0.59 \\
\hline triflumuron & & & 10.24 & 1.27 & 0.41 & 86.35 & 0.21 & 0.89 & 0.04 & 0.59 \\
\hline zeta-cypermethrin & & & 10.24 & 1.27 & 0.41 & 86.35 & 0.21 & 0.89 & 0.04 & 0.59 \\
\hline thiodicarb & & 1.2 & 13.58 & 1.58 & 0.75 & 81.18 & 1.02 & 1.05 & 0.07 & 0.77 \\
\hline aldicarb & & 1.3 & 20.79 & 2.27 & 1.47 & 69.99 & 2.77 & 1.41 & 0.13 & 1.18 \\
\hline acetamiprid & & & 28.55 & 3.00 & 2.25 & 57.95 & 4.65 & 1.79 & 0.20 & 1.62 \\
\hline dimethoate & & 2.1 & 29.10 & 3.05 & 2.31 & 57.09 & 4.78 & 1.82 & 0.20 & 1.65 \\
\hline methomyl & 2 & & 34.29 & 3.54 & 2.83 & 49.04 & 6.04 & 2.07 & 0.25 & 1.94 \\
\hline imidacloprid & & 22 & 35.18 & 3.62 & 2.92 & 47.66 & 6.26 & 2.12 & 0.25 & 1.99 \\
\hline trichlorfon & & & 36.97 & 3.79 & 3.10 & 44.88 & 6.69 & 2.21 & 0.27 & 2.10 \\
\hline monocrotophos & & 3.1 & 54.03 & 5.40 & 4.81 & 18.41 & 10.83 & 3.05 & 0.42 & 3.06 \\
\hline acephate & 3 & & 60.00 & 5.96 & 5.41 & 9.14 & 12.28 & 3.34 & 0.47 & 3.40 \\
\hline methamidophos & & 3.2 & 59.77 & 5.94 & 5.38 & 9.51 & 12.22 & 3.33 & 0.46 & 3.38 \\
\hline methidathion & & & 59.77 & 5.94 & 5.38 & 9.51 & 12.22 & 3.33 & 0.46 & 3.38 \\
\hline
\end{tabular}




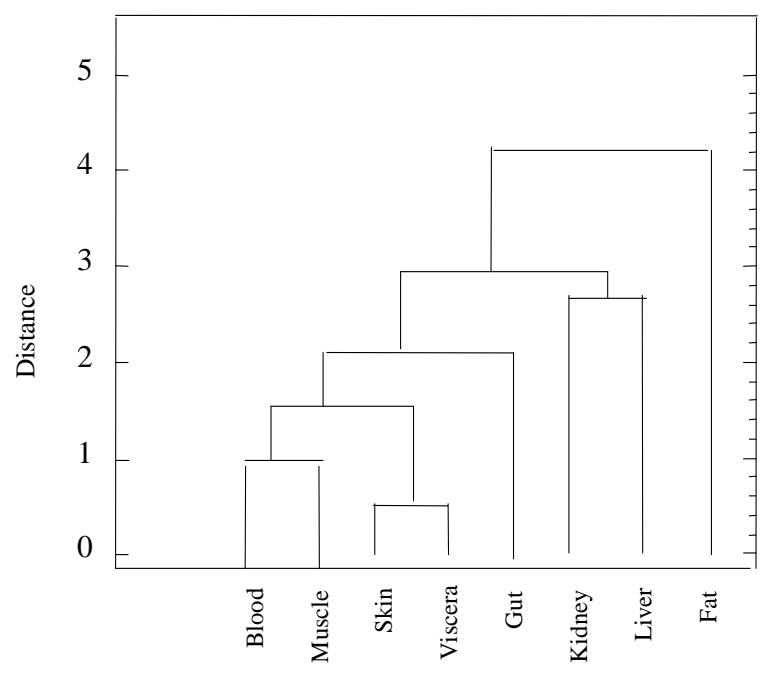

Figure 1 - Dendrogram of human tissue clusters of similar insecticide distribution.

\section{DISCUSSION}

If experimental data on the distribution of a specific insecticide is known, it is possible to infer that any other insecticide of the same subgroup has a similar pattern of distribution among tissues. However, independent of the subgroup, the sum of average percent distribution of insecticides in the muscles and fat was always higher than $50 \%$ or, at least a half of the total insecticide content would be found in muscles and/or fat.

Garcia-Repetto et al. (1997) observed the tissue distribution of $3.0 \mathrm{mg} \mathrm{kg}^{-1}$ of parathion-methyl in rats exposed by via oral and concluded that this insecticide first reached the blood, and then, the liver, brain and fat. After that, it was rapidly redistributed from the latter tissues to the blood again, and finally might accumulate in the adipose tissue. In rats, the adipose tissue seems to be the main sink for parathion-methyl deposition. On the other hand, the biotransformation of insecticides may also produce a non-lipophylic metabolite, which is not suitable to accumulate in adipose tissues and to cross cellular membranes, as in the case of parathion (Machado and Fanta, 2003; Abel et al., 2004).

The organism's absorption and distribution of toxicants depends on the factors related to the compound and to the organism itself, such as the hydrosolubility, liposolubility, ionization degree, among others. The estimated higher fraction in fat tissues might be explained by the low water solubility of most insecticides studied: about $70 \%$ showed water solubility lower than $100 \mathrm{~g} \mathrm{~m}^{-3}$ and $60 \%$ showed $\mathrm{K}_{\mathrm{ow}}$ values higher than $10^{4}\left(\log _{\mathrm{ow}}\right.$ $>4$ ), indicating high lipophylic affinity for the entire group of insecticides.

Kamel et al. (2007) found that increased risk of experiencing more than 10 symptoms had a doserelated association to cumulative exposure to all insecticides, principally to organophosphate and organochlorine, whether or not individuals were excluded with a history of pesticide poisoning or those who had experienced high exposure events. This indicated that moderate insecticide exposure itself was associated with increased risk. It was concluded that experience of neurologic symptoms was related to cumulative lifetime exposure to pesticides, especially by these pesticides.

Thus, knowledge about liposolubility and the potential distribution of the compound in organism can aid in the predictability of possible toxic effects. It is know that some substances accumulate in organism and/or environmental compartments. Due to its liposolubility, organochlorines can be absorbed via skin contact and their accumulation in the human's organism has been related to hepatotoxic and neurologic injuries and reproductive problems, among others. Information about organophosphorus insecticide distribution and its metabolites are also important since they have significant consequences for the treatment of contaminated persons. Further advancements in these aspects may be employed for optimal use of such data for risk assessment purposes. 
Similarly, as liposoluble compounds, these organochlorine and organophosphorus insecticides can be excreted in the milk, affecting the newborn development and causing neurological damages during pre- and post-natal period (Tang et al., 2003; Ribás-Fitó et al., 2005). These findings are also relevant, as children of agricultural workers are considered to have a higher risk of exposure to pesticides compared to the general population because of the close proximity of their homes to the fields where pesticides are applied and from take-home exposure (Quandt et al., 2004).

Another aspect of concern is the increasing damage in reproductive system as the decrease in male fertility observed during the last decades, probably due to estrogenic and anti-androgenic effects during intra-uterine exposure to organochlorines (Nunes and Tajara, 1998; Gore, 2008).

Octanol-water partition coefficient, water solubility and tissue lipid contents are important factors in an insecticide distribution determination in human tissues. The level I fugacity model, insecticide physico-chemical characteristics, tissue volumetric lipid contents, tissue volumes, partition coefficients of octanol-water, octanol-air and airwater can contribute in farmworkers monitoring programs.

In view of that, present work from fugacity model focused on classes of principal insecticides that may cause health damage. The data obtained could aid monitoring programs of compounds with major risk of farmworkers toxicity. Beyond that, further studies using fugacity model in levels II, III and IV can help to better elucidate these questions. Improving epidemiology studies and integrating the present information with the existing toxicology data could allow a more accurately monitoring of farmworkers health risk with low costs.

\section{RESUMO}

O objetivo desse trabalho foi avaliar as características de 39 inseticidas quanto a sua distribuição e acumulação em tecidos humanos como também avaliar o grau de similaridade entre os inseticidas quanto a sua distribuição nos tecidos. Para tanto, foram utilizadas as características físico-químicas dos compostos e o conteúdo de lipídeos teciduais para calcular a distribuição dos inseticidas entre os tecidos estudados. Os inseticidas selecionados para o presente trabalho foram alguns daqueles que se encontram registrados no Brasil para uso agrícola. No cálculo da distribuição dos inseticidas entre os tecidos foi utilizado o modelo de fugacidade nível I em músculos, vísceras, pele, gordura, sangue, fígado, rins e intestinos. As características físicoquímicas dos inseticidas e os conteúdos de lipídio dos tecidos foram usados para calcular a distribuição dos inseticidas entre os tecidos. $\mathrm{O}$ coeficiente de partição octanol-água, a solubilidade em água e o conteúdo de lipídio dos tecidos determinaram a distribuição de um inseticida entre tecidos humanos. Foram realizadas análises de agrupamento, para identificar grupos de inseticidas com distribuição similar nos tecidos. 90\% dos 39 inseticidas apresentaram distribuição em gordura maior do que $50 \%$. A análise de agrupamento indicou três grupos de inseticidas: no primeiro o percentual acumulado na gordura variou de $70-86 \%$, no segundo de $44-58 \%$ e no terceiro de $9-19 \%$. Os resultados obtidos podem contribuir para os programas de monitoramento da saúde do trabalhador rural.

\section{REFERENCES}

Abel, E., Bammler, T., Eaton, D. (2004), Biotransformation of methyl parathion by glutathione S-transferases. Toxicological Sciences, 79, 224-232.

Andersen, M.E., Thomas, R.S., Gaido, K.W., Conolly, R.B. (2005), Dose-response modeling in reproductive toxicology in the systems biology era. Reproductive Toxicology, 19, 327-337.

Caldas, E., Souza, L. (2000), Avaliação de risco crônico da ingestão de resíduos de pesticidas na dieta brasileira. Revista de Saúde Pública, 34, 529-537.

Castro, V., Silveira, M., Perez, M. (1999), Application of clinical indicators of exposition in the evaluation of family agriculture health: the Sumaré case - Brazil. International Journal of Sustainable Development and World Ecology, 6, 172-184.

Cahill, T.M., Mackay, D. (2001), Generalized human physiologically-based pharmacokinetic model for multiple chemical species based on fugacity. Abstracts of Papers of the American Chemical Society, 221, 186-Part 1.

Czub, G., McLachlan, M. (2004), A food chain model to predict the levels of lipophilic organic contaminants in humans. Environmental Toxicology and Chemistry, 23, 2356-2366. 
Dinham, B., Malik, L.L.M.S. (2003) Pesticides and human rights. International Journal of Occupational and Environmental Health, 9, 40-52.

Garcia-Repetto, R., Martinez, D., Repetto, M. (1997), Biodisposition study of the organophosphorus pesticide, methyl-parathion. Bulletin of Environmental Contamination and Toxicology, 59, 901-908.

Gore, A. (2008), Developmental programming and endocrine disruptor effects on reproductive neuroendocrine systems. Frontiers in Neuroendocrinology, 29, 358-374.

Jaga, K., Dharmani, C. (2003), Sources of exposure to and public health implications of organophosphate pesticides. Revista Panamericana de Salud Publica (Pan American Journal of Public Health), 14, 171185.

Kamel, F., Engel, L.S., Gladen, B.C., Hoppin, J.A., Alavanja, M.C.R., Sandler, D.P. (2007), Neurologic symptoms in licensed pesticide applicators in the Agricultural Health Study, Human and Experimental Toxicology, 26, 243-250.

Kissel, J., Robarge, G. (1988), Assessing the elimination of $2,3,7,8$-TCDD from humans with a physiological based pharmacokinetic model. Chemosphere, 17, 2017-2027.

Levigard, Y., Rozemberg, B. (2004), A interpretação dos profissionais de saúde acerca das queixas de "nervos" no meio rural: uma aproximação ao problema das intoxicações por agrotóxicos (Occupational exposure to pesticides and health professionals' interpretation of "nervousness" among rural residents). Cadernos de Saúde Pública, 20, 1515-1524.

Machado, M.R., Fanta, E. (2003), Effects of the organophosphorous methyl parathion on the branchial epithelium of a freshwater fish Metynnis roosevelti. Brazilian Archives of Biology and Technology, 46(3), 361-372.

Mackay, D. (2001), Multimedia environmental models: the fugacity approach. 2.ed. CRC Press Boca Raton, 261p.

Maruyama, W., Yoshida, K., Tanaka, T., Nakanish, J. (2002), Determination of tissue-blood partition coefficients for a physiological model for humans, and estimation of dioxin concentration in tissues. Chemosphere, 46, 975-985.

McKone, T., Macleod, M. (2003), Tracking multiple pathways of human exposure to persistent multimedia pollutants: Regional, continental, and global-scale models. Annual Review of Environment and Resource, 28, 463-492.
Murray, A., Rathbone, A.J., Ray, D.E. (2005), Novel protein targets for organophosphorus pesticides in rat brain. Environmental Toxicology and Pharmacology, 19, 451-454.

Moser, G., McLachlan, M. (2002), Partitioning of polychlorinated biphenyls and hexachlorobenzene into human faeces. Chemosphere, 46, 449-457.

Nunes, M., Tajara, E. (1998), Efeitos tardios dos praguicidas organoclorados no homem (Delayed effects of organochlorine pesticides in man). Revista de Saúde Pública, 32, 372-382.

Paraiba, L.C., Bru, R., Carrasco, J.M. (2002), Level IV fugacity model depending on temperature by a periodic control system. Ecological Modelling, 147(3), 221-232.

Quandt, S.A., Arcury, T.A., Rao, P., Snively, B.M., Camann, D.E., Doran, A.M., Yau, A.Y., Hoppin, J.A., Jackson, D.S. (2004), Agricultural and residential pesticides in wipe samples from farmworker family residences in North Carolina and Virginia. Environ Health Perspect, 112, 382-387.

Ribas-Fitó, N., Grimalt, J., Marco, E., Sala, M., Mazón, C., Sunyer, J. (2005), Breastfeeding and concentrations of HCB and p, $\mathrm{p}^{\prime}$-DDE at the age of 1 year. Environmental Research, 98, 8-13.

Rohlman, D.S., Lasarev, M., Anger, W.K., Scherer, J., Stupfel, J., McCauley, L. (2007), Neurobehavioral performance of adult and adolescent agricultural workers. NeuroToxicology, 28, 374-380.

SAS INSTITUTE SAS/STAT user guide (1998), version 6. Cary, NC, SAS Institute.

SRC [Syracuse Research Corporation] (July, 2005), Available on-line in: http://www.syrres.com/esc/physdemo.htm.

Tang, J., Carr, R., Chambers, J. (2003), The effects of repeated oral exposures to methyl parathion on rat brain cholinesterase and muscarinic receptors during postnatal development. Toxicology Science, 76, 400406.

Tomlin, C. (2000), The pesticide manual. Farnham: British Crop Protection Council, CD-Rom.

Ward, J. (1963), Hierarchical grouping to optimize an objective function. Journal of the American Statistical Association, 58, 236-244.
Received: August 29, 2006; Revised: September 04, 2007; Accepted: December 23, 2008. 